\title{
FAMILY TOURISM AND ITS INFLUENCE ON STUDENTS' BEHAVIOURS AS TOURISTS
}

\begin{abstract}
This research focused on family tourism and its influence on the current interest and participation of students in tourism and on the quality of their lives. The study examined the participants' frequency and limitations on their involvement in family tourism. The results from the study were compared to the current level of tourism activity. The study compared the forms, types of tourism and methods of its organization. Qualitative research provides more precision in examining the results and this study concentrated on the perception of elements within family tourism involvement that improved life quality. The study collected data using the methods of diagnostic survey and structured in-depth interviews. In addition, the study utilized the non-parametric chi-square test and Spearman's rank correlation coefficient for statistical analysis. The study found that there was statistically significant dependence between travelling with parents in the past and the level and quality of current tourism activities of academic students.
\end{abstract}

Keywords: family tourism, family leisure, tourism activity, student's tourism, determinants of tourist activity, family travel, family.

\section{INTRODUCTION}

Tourism is an integral part of the lives of contemporary families which live in developed countries. It gives satisfaction and is a source of joy for them. The importance of tourism and relaxation for the improvement of life satisfaction has been thoroughly analysed in literature. Diener and Suh (1997), and Karnitis (2006) claim that rest and recreation play an important role in the quality of human life. Silverstein and Parker (2002), and Dann (2001) emphasise that valuable pastimes, e.g. practising sports and tourism, are investments aimed at satisfactory experience of late adulthood and old age. When analysing the role of tourism services for the quality of life, Neal, Sirgy and Uysal (2004) have discovered that satisfaction with tourist experiences and reflections on travels have an influence on general life satisfaction. These issues are particularly important in the conditions of swift social changes where families try to stabilise their role and increase coherence (Charles, Davies, Harris, 2008; Hill, 2011). Spending free time together is an element which brings families closer, especially in the sphere of tourism (as argued by Lehto, Lin, Chen, Choi, 2012),

1 Anna Delekta, PhD, Faculty of Social Sciences, Pedagogical University of Krakow, ul. Podchorążych 2, 30-084 Kraków; e-mail: anna.delekta@up.krakow.pl. (corresponding author). ORCID: 0000-0002-1480-3029.

2 Justyna Stecko, PhD, Rzeszów University of Technology, Faculty of Manage- ment, Department of Humanities and Social Sciences; e-mail: jstecko@prz.edu.pl. ORCID: 0000-0001-9968-7946. 
where common tourism or recreation experiences are conducive to the forming and developing of healthy social relationships and emotional bonds among family members (e.g. Gram, 2005; Zabriskie, McCormick, 2001).

The actual consistent presence of adults in the life of a child belongs to the most important factors affecting the future of the child in terms of happiness, academic success, leadership skills or significant relationships (Siegel, Bryson, 2020). It is hard to find situations with greater closeness and company of adults than when travelling. The distancing of family members is reduced when travelling. In contemporary homes, each family member usually has a separate place to stay, clearly defined chores and a plan of activities to perform on their own. Such personal space is usually limited during travels when everyone does the same things at the same time: sightseeing, relaxing on the beach, doing sports, having meals together, etc. This shared personal and time space is a source of jointly experienced joy and misunderstandings solved together. Spending time together without daily duties can also be relaxing for family members. As early as in the 1980s, Harper emphasised that a contemporary family functions in stressful conditions and that family recreation can counteract certain "negative influences" on the group, thus guaranteeing family well-being. He also postulated that programmes aimed at motivating families to joint tourism and sports activities should be promoted (Harper, 1985). His observations remain valid despite the change in the family structure. The observation of family functioning and its impact on a new, developing generation is an interesting topic of research. One of the interesting aspects of family functioning is the development of an active, pro-health attitude which helps learn about the environment and culture. All this is supposed to help raise and educate an individual whose life is of value and brings satisfaction.

There is a group of studies focused on family consumption in the context of research on the tourism market (e.g. Khoo-Lattimore, 2015; Gram, 2007) and families' tourism motives (e.g. Kim, Lehto, 2013). However, when browsing through literature one notices that research on the influence of family tourism on behaviours of adult tourists does not enjoy popularity. Research has been carried out in Poland when examining determinants of tourism activities (Delekta, 2013; Delekta, 2014; Delekta, Stecko, 2016) and in Lviv (Ukraine) with greater focus on the very issue (Delekta, Stecko, 2018). These research studies laid emphasis on the family and family traditions in relation to tourism as some of the most important determinants of tourism activities in the life of an adult.

This research is dynamic; it evaluates and compares family tourism during childhood and adolescence with the current level of tourism activities of the research subjects from the Kiev academic centre.

Students have been chosen as research subjects because of the immense importance of the academic period on the development of the tourist lifestyle. Withdrawal from the influence of a family is a test for a person's tourism development. It is the time when a person enters a stage of stabilised tourism activities (Winiarski, Zdebski, 2008). The period can see the development of tourism preferences independent of the tradition of a family home or, quite on the contrary, based on this tradition. A question arises whether family tourism has a considerable impact on the level of tourism activity of an adult.

H1 hypothesis has been formulated regarding the existence of a dependence between the level and methods of family tourism in the past and the current participation of the research subjects in tourism. 


\section{MATERIALS AND METHODS}

Quantitative and qualitative methods have been used for this research study. Data has been collected using a diagnostic survey and in-depth interviews. Both research procedures are complementary. Triangulation logic (Bryman, 1992) has been applied to integrate both approaches. It involves verification of quality by juxtaposing statements by respondents with quantitative results using recommendations of C. Frankfort-Nachmias, D. Nachmias (2011) and Flick (2011).

Research was conducted in November 2019 on a group of first-cycle students at the Faculty of Geography at the Kiev University. It began with work on the discussed phenomenon in the Kiev academic centre and is to be continued in Kiev in other faculties of the Kiev University and other higher education facilities. A random purposive sample of 126 subjects has been chosen (seven questionnaires have been rejected because incomplete answers have been given). Purposive selection resulted from a need to exclude first-year students from the sampling frame of respondents. This approach was necessary due to preliminary assumptions in accordance with which respondents needed to be adults with a status of a student for at least one year.

The sample is characterised by a prevalence of female respondents, which adequately reflects the sex distribution of respondents from the Faculty of Geography at the Kiev University, where students constitute a general population and a basis for considerations and analysis in this research study. The majority of the respondents live in cities or towns: $43 \%$ of them come from large cities (with a population of more than 100 thousand), 32\% come from medium-sized and small towns, and $25 \%$ come from the countryside. Forty percent of students come from families where both parents have higher education and another $30 \%$ from families with one parent having a diploma of higher education. The majority of respondents are in a good financial condition: $60 \%$ of respondents think that their financial situation is average and $54 \%$ claim that the material standing of their families is average. Sixty-five percent declare that income per capita in their families exceeds average income per capita in Ukraine, $14 \%$ of respondents work for money and as many as $21 \%$ work as volunteers.

The diagnostic survey method has been used when collecting data, with data collected in small, randomly chosen laboratory groups. Research subjects were asked to confirm their willingness to take part in the study. Subsequently, the objective of the study was explained to them and tips were given on how to complete individual parts of the questionnaire. The study was carried out in the mother tongue of respondents (Ukrainian). The researcher was present throughout the duration of the study in case respondents had any questions. The questionnaire was prepared in accordance with collective literature on tourism activity and considered specific observations on the conditions of this activity and barriers to its occurrence. The questionnaire had been tested, used and verified earlier, for example, during similar research studies at the Lviv University in 2018 (Delekta, Stecko, 2018) and in research at several Polish academic centres.

The first part of the questionnaire included questions regarding family travels: planning, organisation, kinds of activities and limitations in travels. The subsequent part focused on the exact identification of the level of tourism activities since respondents reached the age of maturity. That part also included questions regarding pastimes, types of tourism, organisation of tourism and barriers which restrict or disable tourism. The last part included questions aimed at characterisation of a respondent. 
A series of in-depth interviews were carried out with eight students of the Faculty of Geography who were staying at university campus. Interviews were partly structured and concentrated on the current and prior tourism activities and on the perception of problems associated with a selected trip/journey (preparations, course of the trip/journey, postevaluation) and the destination. Interviews elaborated on the topics touched upon in the questionnaire and enabled more precise specification and better understanding.

In order to verify the hypothesis, the frequency of family tourism in the past, types of tourism and methods of its organisation were analysed. Next, it was checked if there was a dependence between these variables and the actual level and quality of tourism activities of respondents.

The following tools were used in the statistical analysis of quantitative material:

a) chi-square independence test to determine the dependence between the current level of students' tourism activities and variables of family tourism such as frequency of family vacations, financial situation of a family, level of parents' education, barriers to tourism, and to determine the dependence between family tourism and current tourism habits. The adopted statistical significant was $p<0.05$.

b) Spearman rank correlation coefficient to analyse the co-dependence and strength of the relationship between kinds of tourism chosen for family vacation and kinds of tourism currently chosen by respondents.

In the last stage, results of quantitative and qualitative research were compared.

It should be added here that this study focuses on family tourism in a strict sense, which includes family vacation understood as travels by spouses with children and by single parents with children, by parents and grandchildren, or by aunts and uncles with their nephews/nieces (Kowalczyk-Anioł, Włodarczyk, 2011).

\section{RESULTS}

Based on the research on the influence of the frequency of tourism practiced with parents in the past on the current level of average tourism activities of students, it is concluded that there is a statistically significant dependence between the analysed variables, $p<0.01$ (Table 1).

Table 1 . Tourist activity with parents in the past and the average frequency of tourist trips during the year

\begin{tabular}{|c|c|c|c|c|c|c|c|c|}
\hline \multirow{3}{*}{$\begin{array}{l}\text { Participation in tourism } \\
\text { with parents in the past }\end{array}$} & \multicolumn{8}{|c|}{$\begin{array}{l}\text { The average frequency of tourist trips during the year } \\
\text { (since the beginning of studies) }\end{array}$} \\
\hline & \multicolumn{2}{|c|}{$\begin{array}{l}\text { Many times } \\
\text { a year }\end{array}$} & \multicolumn{2}{|c|}{ Once per year } & \multicolumn{2}{|c|}{$\begin{array}{c}\text { Once every } \\
\text { few years or } \\
\text { not at all }\end{array}$} & \multicolumn{2}{|c|}{ Total } \\
\hline & $\mathrm{N}$ & $\%$ & $\mathrm{~N}$ & $\%$ & $\mathrm{~N}$ & $\%$ & $\mathbf{N}$ & $\%$ \\
\hline Dozen/several times & 38 & 92.7 & 2 & 4.9 & 1 & 2.4 & 41 & 32.5 \\
\hline Once or twice per year & 37 & 64.9 & 15 & 26.3 & 5 & 8.8 & 57 & 45.2 \\
\hline Not at all & 14 & 50.0 & 7 & 25.0 & 7 & 25.0 & 28 & 22.2 \\
\hline Total & 89 & 70.6 & 24 & 19.0 & 13 & 10.3 & 126 & 100 \\
\hline Test chi $^{2}$ & & & & & & & & \\
\hline
\end{tabular}

Source: Compiled by authors. 
In order to verify and precisely define these dependencies, family vacation is juxtaposed with the level of tourism activity of respondents occurring during the last year (directly before the date of research survey). The statistical analysis shows that the level of statistical significance $p$ is below 0.01 for the analysed variables. Therefore, there is a statistically significant dependence between tourism activities in the past with parents and the frequency of excursions of research subjects during the year preceding the date of research, with the assumption that each of them covered accommodation for at least one night in the visited area (Table 2).

Table 2. Tourist activity with parents in the past and tourist activity in the last year

\begin{tabular}{|c|c|c|c|c|c|c|c|c|}
\hline \multirow{2}{*}{$\begin{array}{c}\text { Participation in } \\
\text { tourism with parents } \\
\text { in the past }\end{array}$} & \multicolumn{6}{|c|}{ Tourist activity in the last year (with a minimum of 1 night's stay) } \\
\cline { 2 - 9 } & \multicolumn{3}{|c|}{$\begin{array}{c}\text { At most once } \\
\text { Two, three } \\
\text { times }\end{array}$} & \multicolumn{2}{c|}{ Many times } & \multicolumn{2}{c|}{ Total } \\
\cline { 2 - 9 } & $\mathrm{N}$ & $\%$ & $\mathrm{~N}$ & $\%$ & $\mathrm{~N}$ & $\%$ & $\mathrm{~N}$ & $\%$ \\
\hline Dozen/several times & 2 & 5.1 & 10 & 25.6 & 27 & 69.2 & $\mathbf{3 9}$ & $\mathbf{3 1 . 0}$ \\
\hline Once or twice per year & 12 & 20.7 & 27 & 46.6 & 19 & 32.8 & $\mathbf{5 8}$ & $\mathbf{4 6 . 0}$ \\
\hline Not at all & 11 & 37.9 & 12 & 41.4 & 6 & 20.7 & $\mathbf{2 9}$ & $\mathbf{2 3 . 0}$ \\
\hline Total & $\mathbf{2 5}$ & $\mathbf{1 9 . 8}$ & $\mathbf{4 9}$ & $\mathbf{3 8 . 9}$ & $\mathbf{5 2}$ & $\mathbf{4 1 . 3}$ & $\mathbf{1 2 6}$ & $\mathbf{1 0 0}$ \\
\hline Test chi & \multicolumn{6}{|c|}{$\mathbf{p}<\mathbf{0 . 0 1}$} \\
\hline
\end{tabular}

Source: Compiled by authors.

The method of tourism organisation used by the families of research subjects in the past also had a significant influence on the current organisation of trips by adults from these families. The juxtaposition of replies concerning entities involved in the organisation of family tourism with replies regarding organisers of tourism chosen by students in adulthood infers the occurrence of statistically significant dependence $(\mathrm{p}=0.006)$. Sixty percent of the respondents whose parents organised tourism on their own in the past currently organise their holidays on their own and at their initiative. Research subjects who used the services of travel agents with their parents in the past tend to imitate this organisation method.

The comparison of the past tourism with parents with currently chosen forms gives the Spearman's rank correlation coefficient equal to 0.88 . This is evidence of a strong positive correlation between the discussed phenomena. The ranks of currently chosen forms of tourism activity reflect the ranks indicated with regard to family tourism in the past. The chart illustrates respondents' replies regarding this matter. 


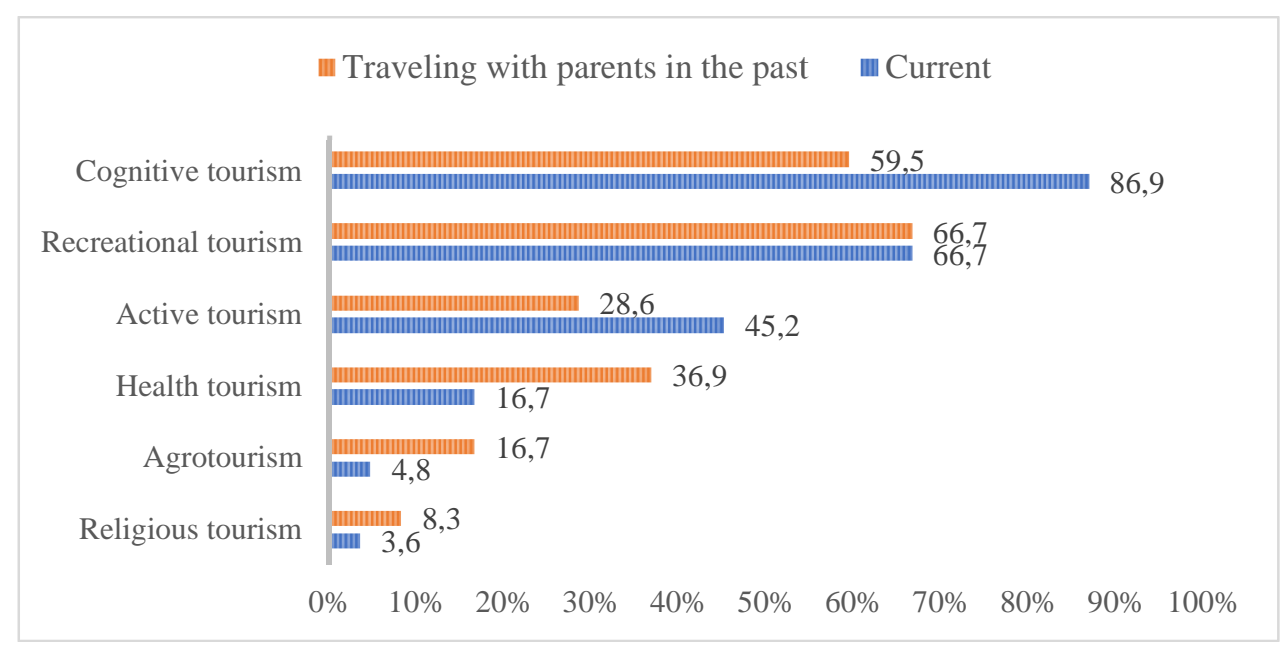

Fig. 1. Types of tourism with parents in the past and types of tourism currently practiced by students Source: Compiled by authors.

The analysis also covers the characteristics of the family which could determine the level and shape of family tourism and the current tourism activities of the subjects. These characteristics include the financial situation of the family, its place of residence, and parents' education level. The family's financial situation turns out to be a significant factor influencing family tourism $(\mathrm{p}<0.001)$ and the current level of tourism activities of the subjects $(\mathrm{p}<0.001)$.

Students' place of residence had no impact on the frequency of family tourism statistical significance higher than assumed, $p=0.07$. The dependence is noted between the student's place of residence (understood as the place of origin) and the current level of tourism activities $(\mathrm{p}=0.01)$. Residents of large cities were those who travelled most frequently during the last year (several or more than a dozen times) whereas respondents from the countryside did not travel at all and were the largest group of respondents.

Based on the analysis, it should be concluded that the education of parents had no influence on family tourism and has no influence on the current tourist behaviour of the subjects. In both sets of variables, $p$ was higher than the assumed value of 0.05 .

The statistically significant dependence also occurs in the juxtaposition of replies regarding the participation in preparations for a family vacation with the level of tourism activities in the previous year $(\mathrm{p}=0.05)$.

Finally, respondents were asked about inhibitors of tourism activities in the past. The lack of parents' free time (63\% of responses), family's material situation (60\%), parents' household chores and the lack of command of foreign languages $(19 \%)$ were the greatest limitations to family tourism. Such limitations as the lack of parents' interest in tourism activities, the lack of suitable companions or of suitable organisation, the fear of changing the surroundings or the health status were of lesser importance. Qualitative research confirms the importance and ranks of these barriers. Only $16.7 \%$ of research subjects declared that there were no limitations to family tourism. 
Based on the above research results, hypothesis H1, saying that family tourism significantly affects the level of tourism activity of research subjects, should be accepted and the null hypothesis regarding the absence of such an influence should be rejected.

\section{DISCUSSION}

Family tourism belongs to the largest markets in the tourism industry and accounts for approximately one third of the entire market of recreational travels (Schanzel, Yeoman, 2015). Research on family tourism and its consequences seems justified and desirable, as pointed out by numerous authors, e.g. Schazel and Yeoman 2014 or Delekta et al. 2018.

Family's pastimes, including the quantity of time devoted to tourism activities with parents during childhood and adolescence, are not indifferent to the frequency of tourism activities during adulthood. These topics are discussed by Kowalczyk-Anioł (2007), Delekta (2014), Delekta, Stecko (2016). Their research conducted among Polish students implies that tourism experience of a family home is the most important determinant of the level of tourism activity of an adult. The mentioned research concerned an influence of various groups of factors (social, economic, demographic, geographic, and others) on participation in tourism. Based on the measurement of the strength of the relationship between factors which would indicate the relationship with tourism activities (with a level of statistical significance $\mathrm{p}<0.05)$, it was noted that travelling with parents had the strongest relationship to the dependent variable (Delekta, 2013). This research also confirms the statistically significant relation between the level of family vacations and the level of current tourism activities of the respondents. It also suggests a strong correlation between types of activities during the analysed time periods.

Research by Delekta $(2013$, 2014) and Delekta, Stecko (2018) implies that the experience from childhood, especially gained during active participation in preparations for the vacation, causes that a person acquires skills and certainty of being an organiser of tourism for their kids or other family members. This has resulted from both quantitative and qualitative research. This quantitative research also confirms the occurrence of such a dependence.

It is envisaged that family vacations will be on the increase at a pace faster than that for any other pastimes, partly due to the fact that vacations reunite a family and are ideas for family members to spend their time together, at a distance from professional duties (Schanzel et al., 2012). In accordance with international research via Expedia, quoted by Lehto et al. (2012), Americans spend most of their holidays by travelling with their closest relatives. Similarly, American Express research (2011) has shown that travelling with the family in the free time is still a priority for the American society. This is also confirmed by statements of respondents who notice the advantages of active time management for the purposes of tourism and declare the implementation of this style of spending their free time with kids in the future.

It should also be noted that, apart from all positive aspects, family tourism can also have debatable implications. Shaw (1992) draws attention to certain aspects of the functioning of the family before and after vacation. She emphasises that the organisation of family activities and the creation of situations which are conducive to relaxation with the family require work and effort. Work is not distributed equally among men and women. Conclusions on this matter should not be drawn from this research but it should be noted that in their free statements respondents more frequently pointed out that mothers were the 
ones who initiated and organised vacations. But this issue requires more detailed examination.

Another question arises: did family tourism take account of children's needs? Was participation in family tourism another duty imposed by parents convinced that this was right? Finding answers to these questions is worthwhile, especially that there are certain premises resulting from qualitative research which suggest the existence of these issues.

In light of the above considerations, it should be noted that family tourism undoubtedly deserves attention not only because it is characterised by a growing trend but also due to the fact that is has important structural consequences in the today's layered society and binds families together, making them stand out and developing the quality of life of the generation to come, through close contact with nature and culture.

\section{CONCLUSION}

The juxtaposed results of quantitative and qualitative research clearly indicate that:

1. The frequency of family vacations in the past has an influence on the frequency of tourism activities in the present time.

2. Types of tourism with parents in the past have a positive correlation to the current types of tourism.

3. There is a relation between the organisation of family tourism and currently chosen methods of organising tourism.

Research results suggest that the hypothesis of the influence of family tourism on the level and quality of present tourism activities of respondents should be accepted.

A practical conclusion is also the fact that research results can be useful to tourism organisers. Literature and this research provide arguments proving that the analysed market segment (families with kids) can treat tourism and recreation excursions as priorities and make decisions in this area regardless of the changing circumstances, e.g. decreased income of the family. As qualitative research shows, this often results from a need and awareness of developing a young generation, investing in the health and education of children, and often also from fashion for tourism. These segments are very attractive to the tourism industry because they are predisposed to minimise susceptibility to unpredictable crises and external shocks.

\section{REFERENCES}

Bryman, A. (1992). Quantitative and qualitative research: further reflections on their integration [In:] Brannen, J., ed., Mixing methods: Qualitative and quantitative research. Aldershot: Avebury.

Charles, N., Davies, C.A., Harris, C.C. (2008). Families in transition: Social change, family formation and kin relationships. Bristol, United Kingdom: Policy Press.

Dann, G.M.S. (2001). Senior tourism and quality of life. "Annals of Tourism Research", 28.

Delekta, A. (2013). Determinanty aktywności $i$ destynacji turystycznych studentów dużego i małego ośrodka akademickiego. Kraków: Wydawnictwo Naukowe Uniwersytetu Pedagogicznego w Krakowie.

Delekta, A. (2014). Społeczne determinanty aktywności turystycznej studentów krakowskiego ośrodka akademickiego. „Humanities and Social Sciences”, Vol. XIX, nr 21 (4).

Delekta, A., Stecko, J. (2016). Social and economic conditions of tourism activity of students in Krakow. "Humanities and Social Sciences", Vol. XXI, 23 (3/2016). 
Delekta, A., Stecko, J. (2018). Family as a determinant of tourist activity of students of the University of Lviv. "Humanities and Social Sciences", Vol. XXIII, 25 (4/2018).

Delekta A., Kurek, S., Mróz, F., Rettingier, R., Ziółkowska-Weiss, K., Żemła, M. (2018). Families with Children as Consumers on the Tourism Market - Research Challenges. "Folia Turistica”, 48 (2018).

Diener, E., Suh, E. (1997). Measuring quality of life: Economic, social, and subjective indicators. "Social Indicators Research", 40.

Flick, U. (2011). Jakość w badaniach naukowych. Warszawa: Wydawnictwo Naukowe PWN. Frankfort-Nachmias, C., Nachmias, D. (2011). Metody badawcze w naukach społecznych. Poznań: Wydawnictwo Zysk i S-ka.

Gram, M. (2005). Family holidays: A qualitative analysisof family holiday experiences. "Scandinavian Journal of Hospitality and Tourism", 5(1).

Gram, M. (2007). Children as co-decision makers in the family? The case of family holidays. “Young Consumers", Vol. 8(1).

Harper, J.A. (1985). Together is better: A model for the development of a national family recreation program. "World Leisure and Recreation Association Journal", 27.

Hill, S.A. (2011). Families: A social class perspective. Los Angeles, CA: Pine Forge Press.

Karnitis, E. (2006). Increasing quality of life as the goal for development of Latvia. "Applied Research in Quality of Life", 1.

Khoo-Lattimore, C., Prayag, G., Cheah, B.L. (2015). Kids on board: Exploring the choice process and vacation needs of Asian parents with young children in resort hotels. „Journal of Hospitality Marketing and Management”, Vol. 24(5).

Kim S., Lehto, X.Y. (2013). Travel by families with children possessing disabilities: Motives and activities. "Tourism Management", Vol. 37(1).

Kowalczyk-Anioł, J. (2007). Rozwój przestrzeni urlopowo-wakacyjnej rodzin studentów Uniwersytetu Łódzkiego, Monografia Naukowa Szlakami Nauki nr 34, Łódź: Łódzkie Towarzystwo Naukowe.

Kowalczyk-Anioł, J., Włodarczyk, B. (2011). Turystyka rodzinna - istota i zakres pojęcia [In:] Śledzińska, J., Włodarczyk, B., ed., Turystyka rodzinna a zachowania prospoteczne, Wydawnictwo PTTK „Kraj”.

Lehto, X.Y., Lin, Y., Chen, Y., Choi, S. (2012). Family Vacation Activities and Family Cohesion. "Journal of Travel \& Tourism Marketing”, 29(8).

Neal, J.D., Sirgy, M.J.,Uysal, M. (2004). Measuring the effect of tourism services on travelers quality of life: Further validation. "Social Indicators Research", 69.

Schänzel, H.A., Yeoman, I. (2015). Trends in family tourism. „Journal of Tourism Futures”, Vol. 1(2).

Schänzel, H.A., Yeoman, I. (2014). The future of family tourism. "Tourism Recreation Research", Vol. 39(3).

Schänzel, H., Yeoman, I., Backer, E., ed. (2012). Family Tourism: Multidisciplinary Perspectives. "Channel View". Bristol.

Shaw, S.M. (1992) Dereifying family leisure: An examination of women'sand men's everyday experiences and perceptions of family time. "Leisure Sciences", 14(4).

Siegel, D.J., Bryson, T.P. (2020). The Power of Showing Up: How Parental Presence Shapes Who Our Kids Become and How Their Brains Get Wired. New York: Ballantine Books.

Silverstein, M., Parker, M. (2002). Leisure activities and quality of life among the oldest old in Sweden. "Research on Aging", 24.

Winiarski, R., Zdebski, J. (2008). Psychologia turystyki. Warszawa: Wydawnictwa Akademickie i Profesjonalne. 
Zabriskie, R., McCormick, B. (2001). The influences of family leisure patterns on perceptions of family functioning. "Family Relations", 50(3).

American Express Company survey [access: 12.12.2019]. Access on the internet: https://about.americanexpress.com/press-release/

DOI: 10.7862/rz.2020.hss.15

The text was submitted to the editorial office: January 2020.

The text was accepted for publication: June 2020. 